\title{
Further radiocarbon dates from Dabangay, a mid- to late Holocene settlement site in western Torres Strait
}

\author{
Duncan Wright ${ }^{1}$ and Geraldine Jacobsen ${ }^{2}$
}

\begin{abstract}
Dabangay, on the island of Mabuyag, is one of only two known mid-Holocene sites in Torres Strait. Eleven new radiocarbon dates, combined with nine previous determinations, clarify its site formation processes and settlement history. The sequence shows two sustained settlement periods between 7239-3211 cal. BP and 1815 cal. BP-present, with little evidence for use during the intervening period. This differs from Badu 15, approximately $15 \mathrm{~km}$ south of Mabuyag, where human activity became sporadic after $6500 \mathrm{cal}$. BP. There is no evidence for a settlement expansion at $2500 \mathrm{BP}$ as observed at other sites in the western Torres Strait. These differences suggest varied human responses to post-glacial marine transgression and the subsequent sea-level high stand in western Torres Strait.
\end{abstract}

\section{Introduction}

Despite its close proximity to regions occupied by humans at least 45,000 years ago, very little is understood about the prehistory of Torres Strait prior to 2000 years ago. Golson (1972:384385) suggested western Torres Strait was occupied by huntergatherer communities before marine transgression, followed by the arrival of Papuan horticulturalists after 6000-5000 years ago. Subsequent studies (Barham 2000; Moore 1979:308-313; Rowland 1985:181) broadly agreed with this model, though the issue of human survival after island formation remained hotly debated. For example, Rowland (1985:131) suggested Torres Strait Islander communities were 'ill equipped to deal with insularity' and perished or abandoned their island homes. Barham (2000:290-292) argued that sustained settlement required sheltered living space and predictable subsistence economies that were not available until 4000 years ago (see also Barham et al. 2004:57).

David et al. (2004:72) reported the first direct evidence for early to mid-Holocene human activity in Torres Strait from the site of Badu 15, on Badu, suggesting 'definitive and sustained human presence between 8000 and 6000 years BP', followed by a 'sporadic presence' between 6000-3500 cal. BP. Long distances between Badu and New Guinea, and increased use of offshore islands in north Australia, suggested visitation of Torres Strait was part of 'systematic territorial and sea-based expansions' (David et al. 2004:74) in both regions during the mid-Holocene. A period of 'sustained settlement' after $3500 \mathrm{cal}$. BP was interpreted as evidence for Austronesian incursion (David et al. 2004:74), but has elsewhere been explained as a 'major demographic expansion of local populations' (McNiven et al. 2006:66) within Torres Strait and mainland Australia (see also Carter 2002; Carter and Lilley 2008). Barham (2000:290) suggested availability of living space increased after 4000 years ago due to

\footnotetext{
${ }^{1}$ School of Humanities, Griffith University, Gold Coast Qld 4222, Australia <d.wright@griffith.edu.au>

${ }^{2}$ Australian Nuclear Science and Technology Organisation, Lucas Heights NSW 2234, Australia <geraldine.jacobsen@ansto.gov.au>
}

beach progradation and sea-level stabilisation. This may have influenced settlement, with low intensity occupation (3800-2600 cal. BP) by marine specialists identified on Pulu (McNiven et al. 2006) and Berberass, near Badu (Crouch et al. 2007). McNiven et al. (2006:49; see also Carter 2002; McNiven et al. 2011:5) suggested a migration of 'Papuan maritime, horticultural and pottery-making peoples to the eastern and western islands of Zenadh Kes [Torres Strait]' after 2600 years ago. This period was also associated with the emergence of a 'Torres Strait Cultural Complex', which involved increasing marine specialisation, a shift in cosmology towards the sea, and fluid links between islands through exchange, warfare, intermarriage and maritime voyaging (Barham 2000:228). This paper presents new findings with relevance to these issues: radiocarbon dates from Dabangay, a mid- to late Holocene settlement site on Mabuyag.

\section{The Dabangay Site}

Mabuyag (Mabuiag) is a small $\left(8 \mathrm{~km}^{2}\right)$ granitic island which lies at the most northerly point of western Torres Strait. Dabangay (previously Dabangai) is an ethnographically significant 'village' situated in a deep embayment on the northeast coast of Mabuyag (Eseli et al. 1998; Haddon 1904). Historical and ethnographic records suggest this area was occupied prior to the arrival of London Missionary Society (LMS) teachers and pearl shelling boats after 1872 (Haddon 1904:162; MacFarlane 1933 as cited in Eseli et al. 1998:28-29). Moresby (1876:60) observed continued occupation of Dabangay during this period by people who lived in huts 'pitched under the shelter of some enormous banyan trees'.

In 2004, a large dugong bone mound was excavated on the Dabangay foreshore (McNiven and Bedingfield 2008). A single $70 \times 70 \mathrm{~cm}$ pit revealed layers of dugong skulls and ribs, dating from approximately $350 \mathrm{cal}$. BP. Glass and metal in the upper $10 \mathrm{~cm}$ of the sequence suggested mound construction continued after European arrival (McNiven and Bedingfield 2008:509). An earlier test pit targeted 'field mounds and ditches' observed to 'underlie the edges of some of the stone-bone-shell mounds, suggesting that they pre-date the latter' (Harris and Ghaleb 1987:28).

In 2006, an area of midden was excavated in the grassy interior of Dabangay (Wright 2011; Wright and Jacobsen in press). Excavation of Square A revealed well-stratified cultural deposits (including stone artefacts, charcoal and faunal remains) dating between 7239-4901 cal. BP (at 2 sigma), followed by a period of increased human activity between $313 \mathrm{cal}$. BP and the present (Wright and Jacobsen in press:Table 2). Burnt large marine vertebrate bone was radiocarbon dated to 6480 $6256 \mathrm{cal}$. BP (at 2 sigma), providing the earliest direct evidence of dugong/marine turtle hunting in Torres Strait. Significant white ant disturbance observed in the upper $90 \mathrm{~cm}$ of the Dabangay midden meant that the age of the SU 2-SU 3 interface (i.e. the mid- to late Holocene transition) could not be resolved. As no clear breaks were observed between the two cultural horizons, it remained uncertain whether or not a settlement hiatus 
existed at Dabangay. Furthermore, the antiquity of the Square A excavation (and, therefore, chronology of human settlement and subsistence at the site) could not be ascertained owing to the absence of suitable organic samples associated with the deepest cultural materials (XU 49).

\section{Additional Excavation Results}

To address the dating issues highlighted above we returned to Dabangay in November 2011 to conduct two 1 x $1 \mathrm{~m}$ excavations. Square B, located $13.5 \mathrm{~m}$ to the west of Square A, was excavated to a depth of $105 \mathrm{~cm}$ before being discontinued owing to white ant disturbance, time constraints and poor preservation of cultural materials. Square C, located $5 \mathrm{~m}$ northwest of Square A, was excavated to a depth of $197 \mathrm{~cm}$ below surface and included $15 \mathrm{~cm}$ of culturally sterile deposits at its base. Both squares were excavated using arbitrary excavation units (XUs), guided by natural changes in stratigraphy. All sediment was wet sieved through a $2.1 \mathrm{~mm}$ mesh, with sediment samples obtained from excavation units and a column cut into the west wall of Square C to collect samples for particle size/pollen/phytolith analysis (Figure 1).

The stratigraphy in Square C was similar to that observed in Square A, with a change from dark, organic rich soil (Stratigraphic Unit [SU] 1-SU 2; Figure 1) to calcareous sand (SU 3-SU 6). The lower, calcareous sand layer was not observed in Square B, with compacted clay continuing to the base, with variation between dark, humic sediment (SU 1-SU 2; Figure 2), light, fine-grained sediment (SU 3) and clay/gravel (SU 4). In Squares A and $\mathrm{C}$ a gradation was observed from mottled silt/ sand (SU 3-SU 4) to coarse-grained, cemented white/yellow sand (SU 5-SU 6). A pH test showed that sediments from both Squares B and C varied from mildly acidic to neutral (4.14-5.46), with a slight increase in acidity in the basal XUs of Square C. Clear stratigraphic boundaries and intact lenses of charcoal, bone and stone suggest overall stratigraphic integrity. Localised mixing was observed in SU 2 and the interface between SUs 2 and 3, associated with pit features in both squares. In Square B, a white ant burrow was excavated separately (as SU $2 b$ in Figure 2) and this unit discarded.

Eleven samples of wood charcoal/hardwood were submitted to the ANSTO and Waikato laboratories for radiocarbon (AMS) dating. Tables 1 and 2 provide a list of all dates from this recent excavation, compared with initial results from Square A. Radiocarbon dates were calibrated with OxCal 4.1 (Bronk Ramsey 2009), using the Southern Hemisphere calibration dataset (SHCal04) (McCormac et al. 2004) for charcoal samples, and the marine calibration dataset (Marine09) for the bone sample with the $\Delta \mathrm{R}$ value of $-63 \pm 44$ years (Sean Ulm pers. comm. 2010). Radiocarbon dates descend in correct chronostratigraphic order, suggesting minimal postdepositional disturbance.

Using the 2 sigma age ranges, AMS C14 dates span the mid- to late Holocene period (6938 cal. BP-present). For Square C, sedimentation rate remained constant in SUs 4 and 5 (i.e. 330-355 g per year, 6938-3349 cal. BP). A substantial decline in sedimentation rate was observed in SU 3 (161 g per year, 3349-1415 cal. BP) before it increased to $256 \mathrm{~g}$ per year in SU 1-SU 2 (1615 cal. BP-present). Square B estimates suggest a low sedimentation rate between 5907 and $3211 \mathrm{cal}$. BP (94 g per year), with a significant increase above this (239-258 g per year). We note that the small sample of radiocarbon dates may have influenced these results.

Results from Squares B and C suggest that mid-Holocene settlement (marked by marine vertebrate bone, lithics and charcoal) dates to between 6938-3211 cal. BP, overlapping with the slightly earlier radiocarbon dates from Square A (7239-6033 cal. BP). A settlement hiatus, represented in the stratigraphy, sedimentation rates and substantial reductions in cultural materials, dates to between 3211-1815 cal. BP. Results from Squares B and C suggest renewed settlement at Dabangay after 1815 cal. BP (Table 1), with the greatest density of cultural materials in the upper XUs of SU 2. European items were dispersed throughout these XUs, suggesting increased activity coincided with LMS and pearl shelling activities on the island.

\section{Discussion and Conclusions}

Previous research at Dabangay revealed a 7300 year settlement chronology for Mabuyag, providing the earliest direct evidence for human subsistence in Torres Strait. Results suggested that increased settlement corresponded with (or immediately preceded) the arrival of Europeans on the island, following a settlement hiatus of 4000-5000 years. Re-excavation of Dabangay supports two principal settlement phases, 7239$3211 \mathrm{cal}$. BP and 1815 cal. BP-present, separated by a period of infrequent visitation between 3211-1815 cal. BP. Historical and archaeological records suggest a marked increase in human activity during the late nineteenth and early twentieth centuries. The shorter, late Holocene settlement chronology previously reported from Square A (300-present) can now be attributed to termite disturbance.

The Dabangay excavations provide insight into midHolocene human activities in western Torres Strait. A period of sustained settlement during the period of marine transgression and sea-level high stand (7239-3317 cal. BP), suggests that 'Islanders' survived the isthmus to island transition, developing new technologies (i.e. dugong/turtle hunting) to support an increased reliance on marine resources (see Wright et al. under review for further details). Whether or not the coastal margins of Badu and Mua were also occupied during this period remains an important subject for future research.

Results suggest a major period of reorganisation on Mabuyag after 3317 cal. BP. The reduction in settlement activity at Dabangay between $3317-1815$ cal. BP is unlikely to represent an absence of people on Mabuyag during this period. Construction on the main beach-flat on the eastern side of Mabuyag recently unearthed a cache of dugong bones at a depth of $3.5 \mathrm{~m}$ below surface. An AMS radiocarbon determination from one dugong rib suggested that beach development (and possibly also human activity) occurred from at least $2412 \pm 31 \mathrm{BP}$ (Wright and Gizu 2012). Cultural materials (including one pottery sherd) were excavated at Mui, also on the east coast, in deposits dating to between 1600-1300 cal. BP (Wright and Dickinson 2009). This fits geomorphic and palaeoecological predictions of beach stabilisation (Barham 2000), increased anthropogenic firing, and reduction in forest cover (Rowe 2006) after 3800 years ago. It supports major demographic expansion within western Torres Strait after 4000 years ago (cf. McNiven et al. 2006). Dabangay adds to a growing literature on dynamic interactions 


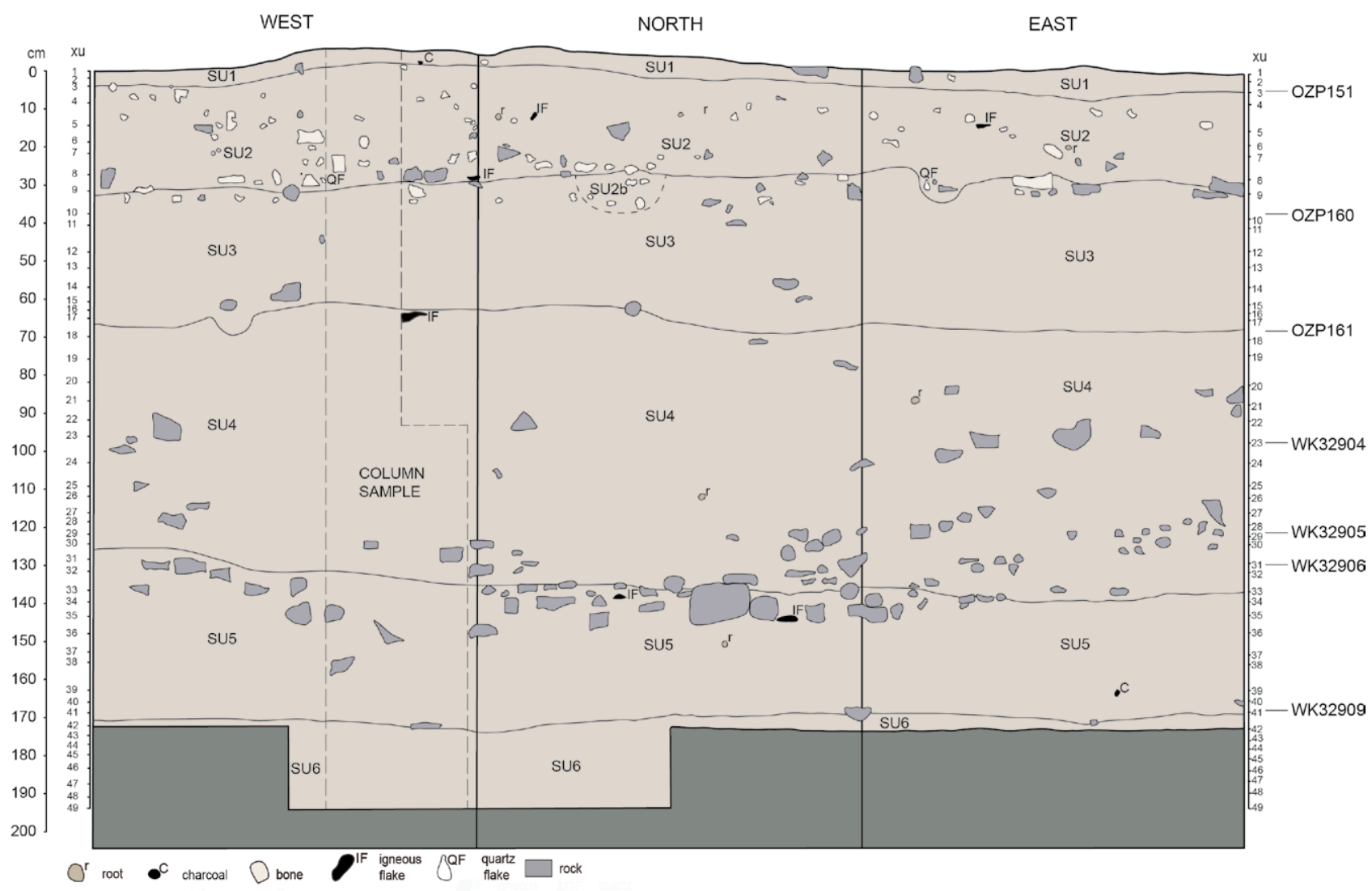

Figure 1 Stratigraphic drawing of Square C.

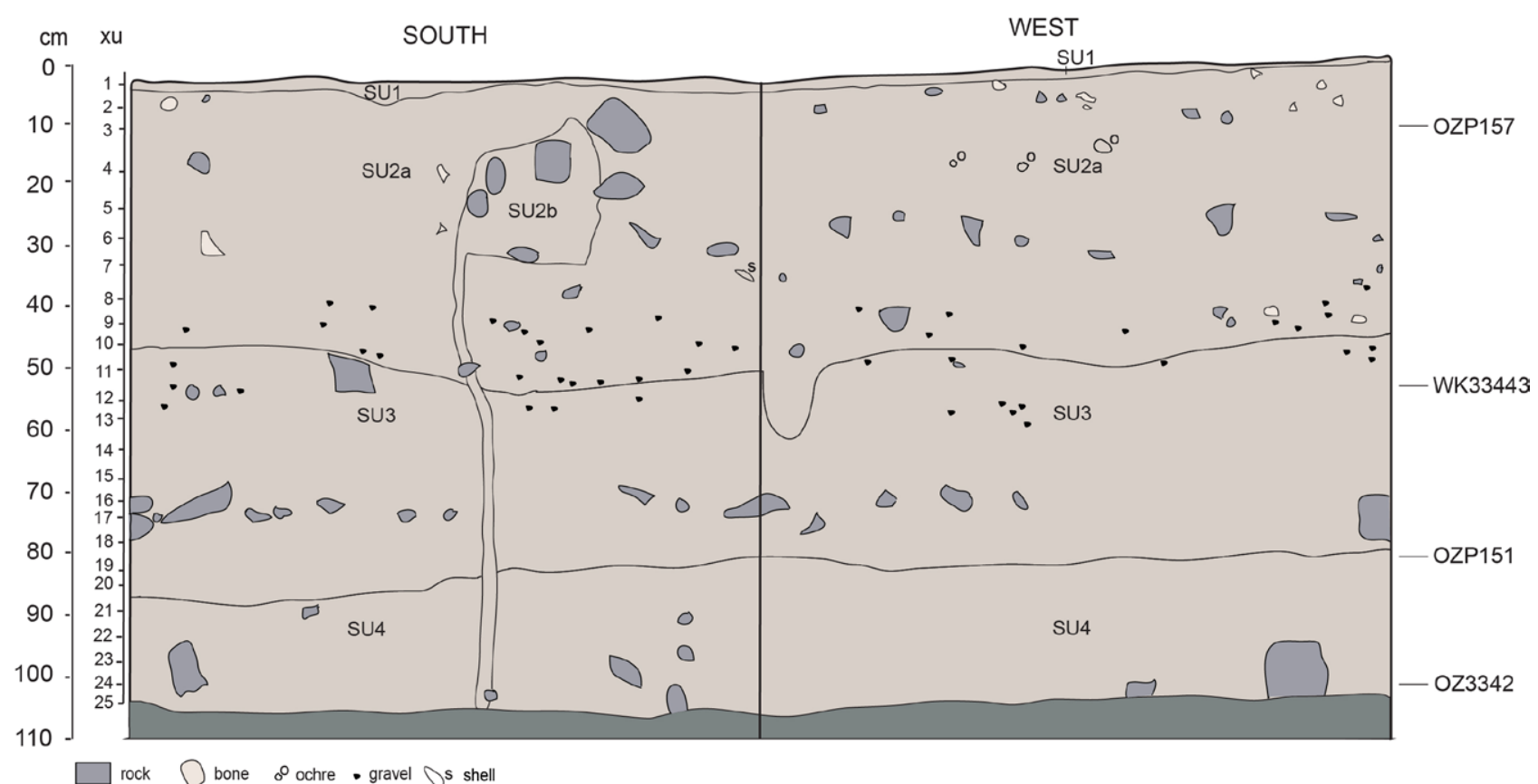

Figure 2 Stratigraphic drawing of Square B. 


\begin{tabular}{|c|c|c|c|c|c|c|c|}
\hline $\begin{array}{l}\text { Lab } \\
\text { Code }\end{array}$ & $\begin{array}{l}\text { Square/ } \\
\mathrm{XU}\end{array}$ & $\begin{array}{l}\text { Depth Below } \\
\text { Surface }(\mathrm{cm})\end{array}$ & $\begin{array}{c}\text { Sample/ } \\
\text { Weight (g) }\end{array}$ & $\delta^{13} \mathrm{C}(\% \circ)$ & $\begin{array}{c}\mathrm{C}^{14} \mathrm{Age} \\
\mathrm{BP}\end{array}$ & $\begin{array}{c}\text { Calibrated Age BP } \\
68.3 \%\end{array}$ & $\begin{array}{c}\text { Calibrated Age BP } \\
95.4 \%\end{array}$ \\
\hline OZP159 & $C, 3$ & $2-4$ & $\begin{array}{c}\text { Charcoal/ } \\
0.16\end{array}$ & $-25.8 \pm 0.1$ & $240 \pm 25$ & $\begin{array}{c}296-279(23.1 \%) \\
205-195(12.9 \%) \\
187-180(8.1 \%) \\
171-154(24.1 \%)\end{array}$ & $\begin{array}{l}306-271(29.9 \%) \\
219-148(65.5 \%)\end{array}$ \\
\hline OXP160 & C, 10 & $27-31$ & $\begin{array}{c}\text { Charcoal/ } \\
0.21\end{array}$ & $-26.9 \pm 0.1$ & $1695 \pm 30$ & $\begin{array}{c}1600-1583(7.7 \%) \\
1570-1515(49.5 \%) \\
1459-1443(7.6 \%) \\
1431-1423(3.4 \%)\end{array}$ & $\begin{array}{c}1684-1678(0.8 \%) \\
1615-1415(94.6 \%)\end{array}$ \\
\hline OZP161 & C, 18 & $67-70$ & $\begin{array}{c}\text { Charcoal/ } \\
0.18\end{array}$ & $-24.5 \pm 0.1$ & $3250 \pm 30$ & $3446-3383(68.2 \%)$ & $3480-3349$ (95.4\%) \\
\hline Wk-32904 & $C, 23$ & $100-104$ & $\begin{array}{l}\text { Hardwood/ } \\
0.22\end{array}$ & $-24.9 \pm 0.2$ & $3924 \pm 32$ & $\begin{array}{c}4406-4367(17.4 \%) \\
4357-4323(16.0 \%) \\
4317-4311(2.7 \%) \\
4304-4240(32.1 \%)\end{array}$ & $\begin{array}{l}4415-4223(83.7 \%) \\
4205-4157(11.7 \%)\end{array}$ \\
\hline Wk-32905 & C, 29 & $120-125$ & $\begin{array}{l}\text { Hardwood/ } \\
1.64\end{array}$ & $-23.3 \pm 0.2$ & $4454 \pm 33$ & $\begin{array}{l}5037-5007(15.4 \%) \\
4980-4875(52.8 \%)\end{array}$ & $\begin{array}{c}5268-5222(3.1 \%) \\
5215-5186(4.2 \%) \\
5120-5112(0.5 \%) \\
5064-4855(87.6 \%)\end{array}$ \\
\hline Wk-32906 & $C, 31$ & $130-132$ & $\begin{array}{l}\text { Hardwood/ } \\
0.2\end{array}$ & $-25.0 \pm 0.2$ & $4359 \pm 34$ & $\begin{array}{l}4958-4936(11.4 \%) \\
4883-4832(56.8 \%)\end{array}$ & $\begin{array}{c}5028-5021(0.7 \%) \\
4974-4825(94.7 \%)\end{array}$ \\
\hline Wk-32909 & C, 41 & $173-177$ & $\begin{array}{c}\text { Acacia?/ } \\
0.55\end{array}$ & $-24.6 \pm 0.2$ & $6052 \pm 29$ & $6889-6786(68.2 \%)$ & $6938-6742(95.4 \%)$ \\
\hline OZP157 & $\mathrm{B}, 4$ & $5-7$ & $\begin{array}{c}\text { Charcoal/ } \\
0.1\end{array}$ & $-26.2 \pm 0.2$ & $95 \pm 25$ & $\begin{array}{c}238-232(4.2 \%) \\
137-115(23.9 \%) \\
60-27(40.0 \%)\end{array}$ & $\begin{array}{c}252-227(9.8 \%) \\
142-82(34.6 \%) \\
74-5(50.9 \%)\end{array}$ \\
\hline Wk-33443 & $\mathrm{B}, 12$ & $49-54$ & $\begin{array}{c}\text { Charcoal/ } \\
0.2\end{array}$ & $-23.3 \pm 0.2$ & $1833 \pm 25$ & $\begin{array}{l}1736-1687(35.0 \%) \\
1674-1621(33.2 \%)\end{array}$ & $1815-1611$ (95.4\%) \\
\hline OZP158 & B, 20 & $99-103$ & $\begin{array}{c}\text { Charcoal/ } \\
0.6\end{array}$ & $-28.2 \pm 0.3$ & $3150 \pm 35$ & $\begin{array}{l}3367-3317(38.1 \%) \\
3308-3264(30.1 \%)\end{array}$ & $3398-3211(95.4 \%)$ \\
\hline Wk-33442 & B, 25 & $117-119$ & $\begin{array}{c}\text { Charcoal/ } \\
0.1\end{array}$ & $-24.6 \pm 0.2$ & $5115 \pm 25$ & $\begin{array}{c}5891-5842(30.6 \%) \\
5832-5804(17.7 \%) \\
5794-5783(6.2 \%) \\
5770-5748(13.6 \%)\end{array}$ & 5907-5728 (95.4\%) \\
\hline
\end{tabular}

Table 1 AMS radiocarbon dates from Squares B and C, Dabangay. Calibrated using OxCal 4.1 (Bronk Ramsay 2009) and SHCal04 dataset (McCormac et al. 2004).

\begin{tabular}{|c|c|c|c|c|c|c|c|}
\hline $\begin{array}{l}\text { Lab } \\
\text { Code }\end{array}$ & $\begin{array}{l}\text { Squarel } \\
\mathbf{X U}\end{array}$ & $\begin{array}{l}\text { Depth Below } \\
\text { Surface }(\mathrm{cm})\end{array}$ & $\begin{array}{c}\text { Sample/ } \\
\text { Weight (g) }\end{array}$ & $\delta^{13} \mathrm{C}(\%)$ & $\begin{array}{c}\mathrm{C}^{14} \mathrm{Age} \\
\mathrm{BP}\end{array}$ & $\begin{array}{c}\text { Callbrated Age BP } \\
68.3 \% *\end{array}$ & $\begin{array}{c}\text { Calibrated Age BP } \\
95.4 \% *\end{array}$ \\
\hline Wk-24928 & 9 & $16-18$ & $\begin{array}{c}\text { Burnt seed/ } \\
0.43\end{array}$ & $-23.4 \pm 0.2$ & $197 \pm 30$ & $226-165$ & 295-136 \\
\hline Wk-24929 & $19 \mathrm{~A}$ & $40-43$ & $\begin{array}{c}\text { Charcoal/ } \\
0.23\end{array}$ & $-25 \pm 0.2$ & $247 \pm 30$ & $301-279$ & $222-147$ \\
\hline Wk-25437 & $25 \mathrm{~A}$ & $56-59$ & $\begin{array}{c}\text { Charcoal/ } \\
0.2\end{array}$ & $-25.4 \pm 0.2$ & $142 \pm 30$ & $125-80$ & $148-0$ \\
\hline OZM308 & 30 & $70-73$ & $\begin{array}{c}\text { Charcoal/ } \\
0.2\end{array}$ & $-24.9 \pm 0.1$ & $175 \pm 40$ & $116-59$ & $155-0$ \\
\hline Wk-25438 & 35 & $90-93$ & $\begin{array}{c}\text { Charcoal/ } \\
0.46\end{array}$ & $-25.4 \pm 0.2$ & $4510 \pm 30$ & $5274-5182$ & 5145-4959 \\
\hline OZM309 & 36 & 102 & $\begin{array}{c}\text { Charcoal/ } \\
0.3\end{array}$ & $-25.4 \pm 0.2$ & $5530 \pm 100$ & 6401-6182 & $6468-5996$ \\
\hline OZM310 & 39 & $124-131$ & $\begin{array}{c}\text { Charcoal/ } \\
0.3\end{array}$ & $-23.6 \pm 0.3$ & $5510 \pm 45$ & 6299-6208 & 6351-6178 \\
\hline Wk-28931 & 46 & $162-164$ & $\begin{array}{c}\text { Burnt bone/ } \\
1.8\end{array}$ & $-9.8 \pm 0.2$ & $6005 \pm 30$ & $6402-6291$ & $6480-6256$ \\
\hline OZM311 & 48 & $166-169$ & $\begin{array}{c}\text { Charcoal/ } \\
0.2\end{array}$ & $-25.4 \pm 0.2$ & $6160 \pm 80$ & 7030-6886 & $7176-6775$ \\
\hline
\end{tabular}

Table 2 AMS radiocarbon dates from Square A, Dabangay. Calibrated using OxCal 4.1 (Bronk Ramsay 2009) and SHCal04 dataset (McCormac et al. 2004). ${ }^{*}=$ highest probability of calibrated ranges. See Wright and Jacobsen (in press) for complete table. 
between people and environment, and provides insight into a 7000 year history of survival and innovation on western Torres Strait islands.

\section{Acknowledgements}

We would like to express our gratitude for AIATSIS fieldwork funding, regrettably one of the last grants before this important resource was put on hold. We thank the Mabuyag community for supporting research and the field crew: Beboy Whap, Lewis Bani, Paula Whap, Shannon Sutton and Matthew Coller for assisting with excavations. We thank Anna Shnukal for her advice on pearl shelling on Mabuyag, Sally May, Ian McNiven, Jeremy Ash, Garrick Hitchcock and Pamela Ricardi for reading drafts of this paper, and Beverley Brigham (GES, Monash University) for assisting with illustrations.

\section{References}

Barham, A.J. 2000 Late Holocene maritime societies in the Torres Strait Islands, northern Australia - cultural arrival or cultural emergence? In S. O'Connor and P. Veth (eds), East of Wallace's Line: Studies of Past and Present Maritime Cultures of the Indo-Pacific Region, pp.223-314. Modern Quaternary Research in Southeast Asia 16. Rotterdam: A.A. Balkema.

Barham, A.J., M. Rowland and G. Hitchcock 2004 Torres Strait Bepotaim: An overview of archaeological and ethnoarchaeological investigations and research. In I.J. McNiven and N. Quinnell (eds), Torres Strait Archaeology and Material Culture, pp.1-72. Memoirs of the Queensland Museum Cultural Heritage Series 3(1). Brisbane: Queensland Museum.

Bronk Ramsay, C. 2009 Bayesian analysis of radiocarbon dates. Radiocarbon 51(1):337-360

Carter, M. 2002 The Murray Islands Archaeological Project: Results of recent archaeological analyses. Australian Aboriginal Studies 2002(2):75-77.

Carter, M. and I. Lilley 2008 Between the Australian and Melanesian realms: The archaeology of the Murray Islands and consideration of a settlement model for Torres Strait. In J. Conolly and M. Campbell (eds), Comparative Island Archaeologies, pp.69-83. British Archaeological Reports 1829. 0xford: Archaeopress.

Crouch, J., I.J. McNiven, B. David, C. Rowe and M. Weisler 2007 Berberass: Marine resource specialisation and environmental change in Torres Strait during the past 4000 years. Archaeology in Oceania 42(2):49-64.

David, B., I.J. McNiven, R. Mitchell, M. Orr, S. Haberle, L. Brady and J. Crouch 2004 Badu 15 and the Papuan-Austronesian settlement of Torres Strait. Archaeology in Oceania 39:65-78.

Eseli, P., A. Shnukal and R. Mitchell (eds) 1998 Eseli's Notebook. Aboriginal and Torres Strait Islander Studies Unit Research Report Series 3. St Lucia: The University of Queensland.

Golson, J. 1972 Land connections, sea barriers and the relationship of Australian and New Guinea prehistory. In D. Walker (ed.), Bridge and Barrier: The Natural and Cultural History of Torres Strait, pp.375-398. Canberra: Research School of Pacific and Asian Studies, The Australian National University.
Haddon, A.C. (ed.) 1904 Sociology, Magic and Religion of the Western Islanders. Cambridge Anthropological Expedition to Torres Strait 5. Cambridge: Cambridge University Press.

Harris, D.R. and B. Ghaleb 1987 Archaeological and ecological investigations on Mabuiag Island. In A.J. Barham and D.R. Harris (eds), Archaeological and Palaeoenvironmental Investigations in Western Torres Strait, Northern Australia. Final Report to the Research and Exploration Committee of the National Geographic Society on Part IIb of the Torres Strait Research Project, July-October 1985, p.35. Unpublished report prepared for the Institute of Archaeology, University of London and Department of Geography.

McCormac, F.G., A.G. Hogg, P.G. Blackwell, C.E. Buck, T.F.G. Higham and P.J. Reimer 2004 SHCal04 Southern Hemisphere Calibration, 0-11.0 cal. kyr BP Radiocarbon 46:1087-1092.

McNiven, I.J. and A. Bedingfield 2008 Past and present marine mammal hunting rates and abundances: Dugong (Dugong dugon) evidence from Dabangai Bone Mound, Torres Strait. Journal of Archaeological Science 35:505-515.

McNiven, I.J., W.R. Dickinson, B. David, M. Weisler, M. Carter and U. Zoppi 2006 Mask Cave: Red-slipped pottery and the Australian-Papuan settlement of Torres Strait. Archaeology in Oceania 41(2):49-82.

McNiven, I.J., B. David, T. Richards, K. Aplin, B. Asmussen, J. Mialanes, M. Leavesley, P. Faulkner and S. Ulm 2011 New direction in human colonisation of the Pacific: Lapita settlement of south coast New Guinea. Australian Archaeology 72:1-6.

Moore, D.R. 1979 Islanders and Aborigines at Cape York. Canberra: Australian Institute of Aboriginal Studies.

Moresby, J. 1876 New Guinea and Polynesia: Discoveries and Surveys in New Guinea and the D'Entrecasteaux Islands. London: John Murray.

Rowe, C. 2006 Landscapes in western Torres Strait history. In B. David, B. Barker and I.J. McNiven (eds), The Social Archaeology of Indigenous Societies, pp.270-286. Canberra: Aboriginal Studies Press and The Australian National University.

Rowland, M.J. 1985 Archaeological investigations on Moa and Naghi Islands, western Torres Strait. Australian Archaeology 21:119-132.

Wright, D. 2011 Mid-Holocene maritime economy in the western Torres Strait. Archaeology in Oceania 46:23-27.

Wright, D. and W.Gizu 2012 How Long have People been Living at Bau? Unpublished report prepared for the Goemulgaw Kod, Mabuiag Island.

Wright, D. and W.R. Dickinson 2009 Movement of ideas not materials: Locally manufactured pottery on Mabuyag Island, western Torres Strait. Archaeology in Oceania 44(1):38-41.

Wright, D. and G. Jacobsen in press Convergence of ceremonial and secular: The archaeology of Dabangay on Mabuyag in the western Torres Strait. In I.J. McNiven and G. Hitchcock (eds), Goemulgal: Natural and Cultural Histories of the Mabuyag Islands, Zenadh Kes (Torres Strait). Memoirs of the Queensland Museum Cultural Heritage Series. Brisbane: Queensland Museum. Accepted for publication 15 January 2011.

Wright, D., P. Hiscock and K. Aplin under review Re-excavation of Dabangay, a midHolocene settlement site on Mabuyag in western Torres Strait. Submitted to Queensland Archaeological Research. 